\title{
Cytotoxicity and Antioxidant Potentials of Barringtonia Asiatica Essential Oil
}

\author{
Isaac John Umaru ${ }^{1,2 *}$, Chinedu Imo ${ }^{2}$, Kayode Arowora ${ }^{2}$, Silas Verwiyah Tatah ${ }^{2}$ and Hauwa A Umaru ${ }^{3}$ \\ ${ }^{1}$ Faculty of Resource Science and Technology, University of Malaysia Sarawak, Malaysia \\ ${ }^{2}$ Department of Biochemistry, Federal University, Nigeria \\ ${ }^{3}$ Department of Biochemistry, Modibo Adama University of Technology, Nigeria
}

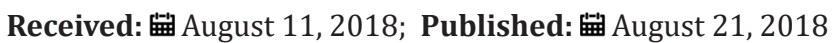

*Corresponding author: Isaac John Umaru, Faculty of Resource Science and Technology, University of Malaysia Sarawak, Malaysia

\begin{abstract}
Essential oils are liquid mixture of volatile compound obtained from aromatic plants. It was observed that many essential oils have antioxidant properties and can present antimicrobial activities. The Aim of the present study were:

a) to determine the cytotoxicity lethality of the leafs and stem-bark of Barringtonia asiatica using brine shrimp (Artimia salina).

b) to evaluate the antioxidant potential of composition of the leaf and stem-bark essential oil using the DPPH (2,2-diphenyl-1picrylhydrazyl) free radical scavenging assay. The essential oil exhibited a mild toxicity and significant IC50 of $36.55 \mu \mathrm{g} / \mathrm{mL}$ and $22.10 \mu \mathrm{g} / \mathrm{mL}$ value of antioxidant potential leaf and stem-bark of Barringtonia asiatica respectively.
\end{abstract}

Keywords: Barringtonia asiatica; essential oil; cytotoxicity; antioxidant

\section{Introduction}

Right from ancient time drugs of plants have been used as herbal formulations in crude forms, like tinctures, teas, powders and poultices, for their growing interest as alternative therapies for the prevention or treatment of various diseases [1]. Essential oils from medicinal and aromatic plants are still considered as rich sources of a huge number of antimicrobial and antifungal components [2]. Many of them show a great potential as anticancer therapeutic agents [3]. However, essential oils are chemically characterized as complex mixtures of low molecular weight compounds and, some of them, are highly volatile and capable of generating flavors and aromas [4]. Scientific studies have shown the role of essential oils in biological interactions among plants and their potential therapeutic including anti-inflammatory, analgesic, anti-tumor, antifungal, and antibacterial activities [59]. In addition to the above-mentioned properties, many essential oils have been confirmed to possess antioxidant activity. They are extremely important for disease prevention, since they inhibit and delay the oxidation of biomolecules by preventing the initiation or propagation of chain oxidation reactions [10-12]. Thus, because of the harmful effects that synthetic antioxidants may cause, such as toxicity and carcinogenicity, the interest in the discovery of natural antioxidants has increased considerably [13]. The growing interest in natural bioactive compounds has led to conduct further studies addressing the replacement of synthetic chemical agents in the industrial sector, since natural products are less harmful to health [14], in addition to being biodegradable and usually exhibiting low toxicity in mammals [15]. This plant Barringtonia asiatica was considered to extract and test for its cytotoxicity and antioxidant potentials. However, Barringtonia asiatica is one of the species belonging to the family Barringtonia, native to mangrove habitats on the tropical, it is a common plant in the Malaysian Mangroves and wetlands such as the Kuching wetlands Sarawak and Bako National Park, it is also found in tropical Africa, Nigeria and Madagascar. Other species belonging to this genus are Barringtonia racemosa, Barrington acutangula, Barringtonia edilus, Barringtonia lanceolate, Barringtonia macrostachya, and Barringtonia spicata [16]. The literature survey revealed that there are no scientific 
studies carried out regarding antioxidant and cytotoxicity of the essential oil of the leaves, stem- barks of Barringtonia asiatica. Hence, the present study is focused to evaluate the antioxidant potentials including determining cytotoxicity (leafs and stembarks) by using Artemia salina and 2,2-diphenyl-1-picrylhydrazyl.

\section{Materials and Methods}

\section{Extraction of Essential Oil}

The plant samples were subjected to water distillation for 8 hours using Clevenger apparatus to extract the oils quantitatively, according to method described by Samsiah et al. [17] and Fasihuddin \& Ibrahim [18]. Approximately $100 \mathrm{~g}$ of fresh cut and ground samples of Barringtonia asiatica leaf and stem bark were weighted, transferred into $2 \mathrm{~L}$ round flask and mixed with $1.35 \mathrm{~L}$ of distilled water. The flask was assembled to the Clevenger trap, connected to the condenser and heated. The sample was heated for 8 hours for hydro distillation process. After 8 hours, the oil trapped in the Clevenger was left to cool at room temperature. The water layer at the bottom of the oil was first drained out to separate it with the oil. The collected oily layer was treated with anhydrous sodium sulphate to remove any trace of water. The experiment was performed triplicates for each sample. The essential oil obtained was kept in a vial and stored in refrigerator at $4{ }^{\circ} \mathrm{C}$ prior to analysis.

\section{Brine Shrimp (Artemia salina) Lethality Test}

Toxicity test against brine shrimp (Artemia salina) developed by McLaughlin et al. [19] was used in this study. Leached brine shrimp eggs were hatched in seawater and incubated for 48 hours at $25^{\circ} \mathrm{C}$. Exactly $3 \mathrm{mg}$ of sample was dissolved in $3 \mathrm{~mL}$ methanol, and the mixture was sonicated to ensure homogeneity of the extract. Four different volumes of 500, 250, 50 and $5 \mu \mathrm{L}$ each from the stock solution were transferred into NUNC multidish in triplicate. Solvent was allowed to evaporate under a running fume hood for overnight and followed by the addition of $0.2 \mathrm{~mL}$ DMSO and $4.8 \mathrm{~mL}$ seawater to give final concentration of $100,50,10$ and $1 \mu \mathrm{g} / \mathrm{mL}$, respectively. Ten brine shrimp nauplii were transferred into each concentration in NUNC multidish, and was observed every 6 hours for 24 hours. The amount of dead nauplii were calculated. Thymol was used as positive control, whereas $0.2 \mathrm{~mL}$ DMSO and $4.8 \mathrm{~mL}$ seawater was used as negative control. The data was analysed to determine the concentration of the samples that kill $50 \%$ of brine shrimp at 24 hours or known as LC50. LC50 was calculated and determined by performing Probit analysis in IBM SPSS Statistic software of version 21.

\section{DPPH (2,2-diphenyl-1-pycryl-hydrazyl) Free Radical Scavenging Assay}

The free radical scavenging assay of compound 2,2-diphenyl1-pycryl-hydrazyl (DPPH) was used to evaluate the antioxidant properties of the crude extract and the essential oil. The measurement was based on the method described by Wang et al. [20]. The sample was prepared by diluting $6 \mathrm{mg}$ of crude extract into $6 \mathrm{~mL}$ of methanol, producing a concentration of $1000 \mu \mathrm{g} / \mathrm{mL}$. The stock solution was sonicated to ensure the homogeneity of the sample. Three other concentrations were prepared at 10, 50 and $100 \mu \mathrm{g} / \mathrm{mL}$, diluted from the $1000 \mu \mathrm{g} / \mathrm{mL}$ stock solution. Sample of $5000 \mu \mathrm{g} / \mathrm{mL}$ was prepared separately by diluting $25 \mathrm{mg}$ of crude extract into $5 \mathrm{~mL}$ of methanol. Approximately $3 \mathrm{~mL}$ of $0.1 \mathrm{mM}$ solution of 2,2-diphenyl-1-pycrylhydrazyl (DPPH) in methanol was each added into five series of prepared concentrations $(10,50,100$, 1000 and $5000 \mu \mathrm{g} / \mathrm{mL}$ ) of sample solutions (1mL). Analysis was done in triplicate. The solution was mixed vigorously and left to stand at room temperature for 30 minutes in the dark after which its absorbance was measured spectrophotometrically at $517 \mathrm{~nm}$ using Jasco ultra violet spectrophotometer model V-630. Methanol was used as blank (only methanol) and negative control (1 $\mathrm{mL}$ methanol mixed with $3 \mathrm{~mL}$ DPPH), while ascorbic acid (vitamin C) as the standard. The concentration of the sample required to inhibit $50 \%$ of the DPPH free radical was calculated as IC50 and the value was determined using Log dose inhibition curve which performed by using PRISM version 3.02 software, based on the calculated values of the DPPH scavenging activity (\%) of the sample [21]. DPPH scavenging activity (\%) was calculated with formula = A0 - A1/A0 x 100, where A0 was the absorbance of the control, while $\mathrm{A} 1$ was the absorbance in presence of the sample. making a concentration of $1000 \mu \mathrm{g} / \mathrm{mL}$. The procedure used was similar to the procedure used to evaluate the antioxidant properties of the crude extract, as mentioned earlier.

\section{Statistical Analysis}

Statistical analysis for biological activities was performed using SPSS programme. The LC50 values for toxicity assay was calculated using the Probit Analysis option in the SPSS. The IC50 for DPPH free radical scavenging assay was statistically determined using Log dose inhibition curve in PRISM programme.

\section{Results}

The plant samples were subjected to water distillation for 8 hours using Clevenger apparatus to extract the oils quantitatively. The antioxidant studies of the essential oils of Barringtonia asiatica leaves and stem bark extract indicated higher scavenging activity against DPPH with the IC50 values of 36.55 and $22.10 \mu \mathrm{g} / \mathrm{mL}$ respectively. The result also suggested that, the Leaves and stembark cytotoxicity LC50 are 56.87 and $457.63 \mu \mathrm{g} / \mathrm{mL}$ for the essential oil. This show the cytotoxicity of the oil. The samples of Barringtonia asiatica leaves and stem bark extract might capture less free radicals formed by DPPH resulting an increase of absorbance and decrease in IC50 value (Tables 1 \& 2) and (Figure 1). 
Table 1: Average death of Artemia salina at different concentrations of essential oils of Leafs and Stem-bark of Barringtonia asiatica.

\begin{tabular}{|c|c|c|c|c|c|c|c|}
\hline \multirow{2}{*}{$\begin{array}{c}\text { Essential oils } \\
\text { Sample }\end{array}$} & \multicolumn{6}{|c|}{ Average death of Artemia salina Concentration $(\mu \mathrm{g} / \mathrm{mL})$} & \multirow[t]{2}{*}{$\mathrm{LC} 50(\mu \mathrm{g} / \mathrm{mL})$} \\
\hline & 1 & 10 & 20 & 100 & & & \\
\hline Leaves & & 0 & $1 \pm 0.53$ & $3 \pm 0.49$ & $7 \pm 7.87$ & & 56.87 \\
\hline Stem-bark & 0 & $1 \pm 0.36$ & $2 \pm 0.46$ & $2 \pm 0.23$ & & 457.63 & \\
\hline (-ve Control) & & 0 & 0 & 0 & 0 & - & \\
\hline $\begin{array}{c}\text { (+ve control) } \\
\text { Thymol }\end{array}$ & $5 \pm 0.56$ & $6 \pm 0.89$ & $10 \pm 0.00$ & $10 \pm 0.00$ & 1.17 & & \\
\hline
\end{tabular}

Table 2: IC50 value of Leaves and stem -bark of Barringtonia asiatica essential oil extract.

\begin{tabular}{|c|c|c|c|}
\hline Plant parts & Crude Extracts & R2 & $\mathbf{I C}_{\mathbf{5 0}}(\boldsymbol{\mu g} / \mathbf{m L})$ \\
\hline Leaves & Control & 0.9751 & 10.52 \\
\hline \multirow{2}{*}{} & Leaves & 0.9434 & 36.55 \\
\cline { 2 - 4 } & Stem-bark & 0.9608 & 22.1 \\
\hline
\end{tabular}

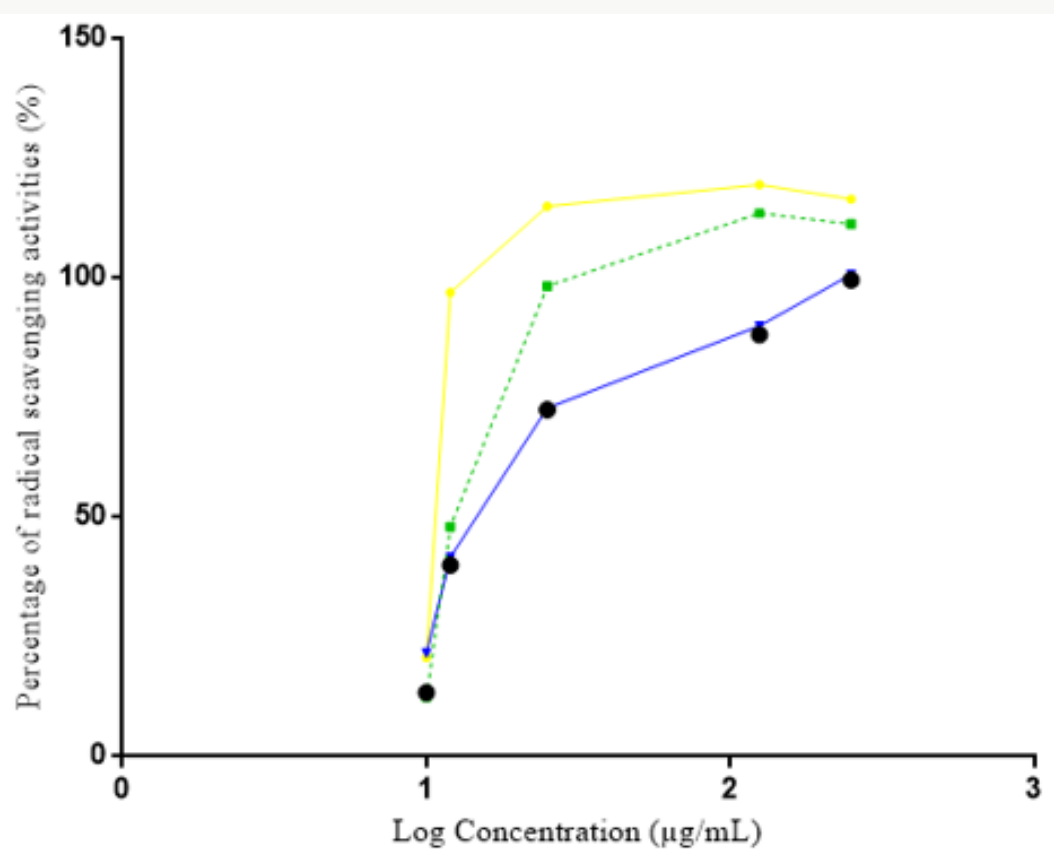

- Leaves

-... Stem-bark Ascobic acid

Figure 1: Graph: $\mathrm{IC}_{50}$ value of Leaves and stem essential oil extract of Barringtonia asiatica.

\section{Discussion}

The essential oil of the plant parts of Barringtonia asiatica tested showed a significant lervical activity when compared with the control and the report of [22]. The lethality concentration of the leaves and the stem-bark essential oil were observed at $1 \mu \mathrm{g} / \mathrm{mL}$ $-100 \mu \mathrm{g} / \mathrm{mL}$ as presented on the table above. The cytotoxicity for the leaves and the stem-bark essential oil LC50 to be $(56.87 \mu \mathrm{g} / \mathrm{mL}$ and $457.63 \mu \mathrm{g} / \mathrm{mL}$ ) respectively. The leaves were indicated to be higher when compared to the is positive control (Thymol) LC50 (1.17) and very toxic when compared to the fact that less than $1000 \mu \mathrm{g} / \mathrm{mL}$ toxic as reported by Meyer et al. [22]. Antioxidants are tremendously important substances which possess the ability to protect the body from damage caused by free radical induced oxidative stress. The antioxidant potential of the essential oil of Barringtonia asiatica leaves and stem-bark extracts was investigated in the search for new bioactive compounds from natural resources. It became clear that the Barringtonia asiatica leaves and stem-bark oil present the highest antioxidant activity compared with reference Antioxidant Vitamin C for DPPH scavenging activity. However, differences of essential oil's antioxidant activity might be observed in some species which may likely be different in different location due to the variation in their chemical composition [23]. Thus, the leaves and stem-bark extract showed a good antioxidant activity with IC50 value of ( 10.52 and $36.55 \mu \mathrm{g} / \mathrm{mL}$ ) respectively. This indicated that the plant parts of Barringtonia asiatica shown a promising candidate for use as natural products based-antioxidant for the health of human being.

\section{Conclusion}

This study showed that Barringtonia asiatica (L.) essential oil from leaves and Stem-bark have high antioxidant activity. Thus, 
further studies should be carried out to establish the bioactive compound, its application and practicability of incorporating Barringtonia asiatica (L.) essential oil in any healthy processed products such as capsulated daily supplements.

\section{Acknowledgement}

The authors acknowledge to Federal University Wukari for study fellow and Universiti Malaysia Sarawak for Laboratory facility and the support of ZAMALA UNIMAS.

\section{References}

1. Chhetri BK, Ali NAA, Setzer WN (2015) A survey of chemical compositions and biological activities of Yemeni aromatic medicinal plants. Medicines 2(2): 67-92.

2. Said-Al Ahl HA, Sarhan AM, Dahab ADMA, Abou-Zeid ESN, Ali MS, et al. (2015) Essential Oils of Anethum graveolens L.: Chemical Composition and Their Antimicrobial Activities at Vegetative, Flowering and Fruiting Stages of Development. International Journal of Plant Science and Ecology 1(3): 98-102.

3. Russo R, Corasaniti MT, Bagetta G, Morrone LA (2015) Exploitation of cytotoxicity of some essential oils for translation in cancer therapy. Evidence-Based Complementary and Alternative Medicine.

4. Trombetta D, Castelli F, Sarpietro MG, Venuti V, Cristani M, et al. (2005) Mechanisms of antibacterial action of three monoterpenes. Antimicrobial agents and chemotherapy 49(6): 2474-2478.

5. SIANI AC, Siani AC, SIANI AC, SIANI AC, Siani AC, et al. (2000) Óleos essenciais: potencial antiinflamatório. 16: 38-43.

6. Silva J, Abebe W, Sousa SM, Duarte VG, Machado MIL, et al. (2003) Analgesic and anti-inflammatory effects of essential oils of Eucalyptus. Journal of ethnopharmacology 89(2-3): 277-283.

7. De Sousa AC, Gattass CR, Alviano DS, Alviano CS, Blank AF, et al. (2004) Melissa officinalis L. essential oil: antitumoral and antioxidant activities. Journal of pharmacy and pharmacology 56(5): 677-681.

8. Osei-Safo D, Addae-Mensah I, Garneau FX, Koumaglo HK (2010) A comparative study of the antimicrobial activity of the leaf essential oils of chemo-varieties of Clausena anisata (Willd.) Hook. f. ex Benth. Industrial Crops and Products 32(3): 634-638.

9. Kaileh M, Berghe WV, Boone E, Essawi T, Haegeman G (2007) Screening of indigenous Palestinian medicinal plants for potential anti-inflammatory and cytotoxic activity. Journal of ethnopharmacology 113(3): 510-516.

10. Kaur C, Kapoor HC (2001) Antioxidants in fruits and vegetables-the millennium's health. International journal of food science \& technology 36(7): 703-725.
11. Bamoniri A, Ebrahimabadi AH, Mazoochi A, Behpour M, Kashi FJ, et al. (2010) Antioxidant and antimicrobial activity evaluation and essential oil analysis of Semenovia tragioides Boiss. from Iran. Food chemistry 122(3): 553-558.

12. Pandini JA, Pinto FGS, Scur MC, Santana CB, Costa WF, et al. (2017) Chemical composition, antimicrobial and antioxidant potential of the essential oil of Guarea kunthiana A. Juss. Brazilian Journal of Biology (ahead) 78(1): 53-60.

13. Losso JN, Shahidi F, Bagchi D (Eds.) (2007) Anti-angiogenic functional and medical foods. CRC Press.

14. Gao CY, Lu YH, Tian CR, Xu JG, Guo XP, et al. (2011) Main nutrients, phenolics, antioxidant activity, DNA damage protective effect and microstructure of Sphallerocarpus gracilis root at different harvest time. Food chemistry 127(2): 615-622.

15. Figueiredo AC, Barroso JG, Pedro LG, Scheffer JJ (2008) Factors affecting secondary metabolite production in plants: volatile components and essential oils. Flavour and Fragrance journal 23(4): 213-226.

16. Isaac John Umaru, Fasihuddin A, Badruddin, Zaini B Assim, Hauwa A Umaru (2018) Cytotoxicity (Brine shrimp Lethality Bioassay) of Barringtonia racemosa Leaves, Stem-Bark and Root Extract. Journal of Biotechnology and Bioengineering 2(2): 45-50.

17. Samsiah J, Fasihuddin BA, Laily D, Zuriati Z (2015) Essential oils from different parts of Goniothalamus ridleyi plant. Sains Malaysiana 44(11): 1579-1585.

18. Fasihuddin BA, Ibrahim J (2003) Chemical constituents of the essential oils of Goniothalamus uvariodes King. Flavour and Fragrance Journal 18(2): 128-130.

19. McLaughlin JL (1991) Crown gall tumours on potato disc and brine shrimp lethality: two simple bioassays for higher plants screening and fractionation. Assay for Bioactivity. San Diego: Academic Press. pp. 2-32.

20.Wang H, Zhao M, Yang B, Jiang Y, Rao G (2008) Identification of polyphenols in tobacco leaf and their antioxidant and antimicrobial activities. Food Chemistry 107(4): 1399-1406.

21. Tailor CS, Goyal A (2014) Antioxidant activity by DPPH radical scavenging method of Ageratum conyzoides Linn. leaves. American Journal of Ethnomedicine 1(4): 244-249.

22. Meyer BN, Ferrigni NR, Putnam JE, Jacobsen LB, Nichols DE, et al. (1982) Brine shrimp: a convenient general bioassay for active plants constituents. Plant Med 45(5): 31-34.

23. Pattamapan L, Kittisak S, Phanida P, Worawan K, Krit T, et al. (2015) In vitro biological activities of black pepper essential oil and its major components relevant to the prevention of Alzheimer's disease. The Thai Journal of Pharmaceutical Sciences 39(3): 94-101.

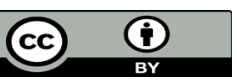

This work is licensed under Creative Commons Attribution 4.0 License

Submission Link:

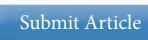

DOI: $10.32474 /$ DDIPIJ.2018.02.000131

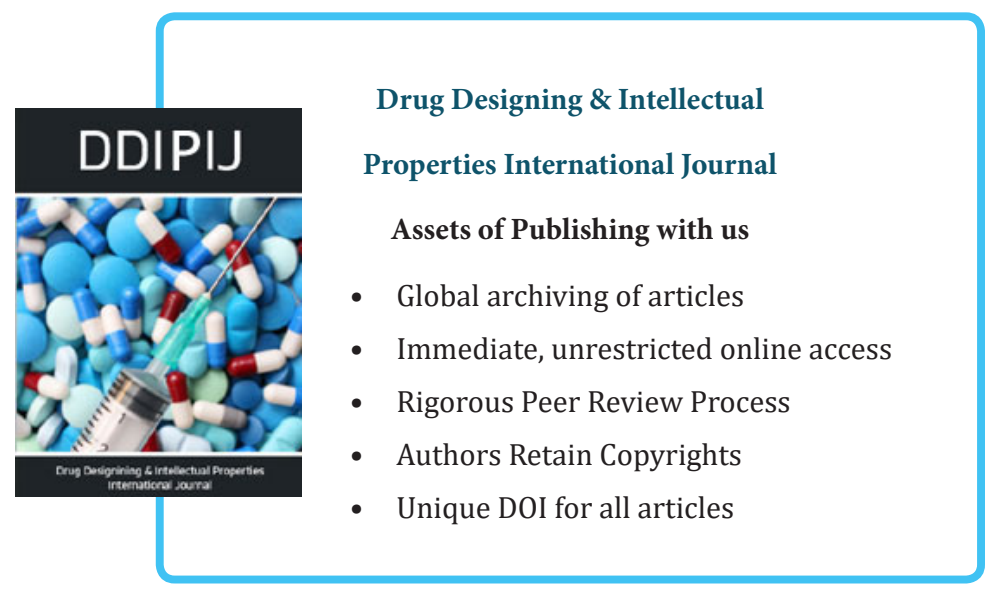

